\title{
Synthesis and Spectroscopic Properties of Optical Probe Based on Schiff Base with Biological Application
}

\section{Mevlüt BAYRAKCI ${ }^{1 *}$, Bahar YILMAZ ${ }^{2}$}

\begin{abstract}
A series of facile optical probe has been easily developed by a one-step Schiff base type reaction of 2,4-dihydroxybenzaldehyde and ortho, meta or para aminophenol. Schiff base compounds as fluorescence sensor were utilized to identify metal ions by spectrophotometric techniques. The data of absorption and emission spectra displayed the extraordinary selective and sensitive sensor properties for Schiff base probe derived from ortho aminophenol (SB-2) toward $\mathrm{Al}^{3+}$ ions. Upon introducing $\mathrm{Al}^{3+}$ ions, an excellent increase in the fluorescence intensity of the probe (SB-2) resulting in color change was observed because of blocking the photoinduced electron transfer (PET) mechanism of azomethine unit. The specific bonding mode of probe (SB-2) with $\mathrm{Al}^{3+}$ was verified by using a series of spectroscopic techniques such as FT-IR, ${ }^{1} \mathrm{H}$ NMR, and UV-vis (Job-plot data). The detection limit of probe (SB-2) toward $\mathrm{Al}^{3+}$ was determined around $10^{-7} \mathrm{M}$. Furthermore, cell imaging studies of probe (SB-2) were also performed and from these experiments, it was seen that the presence of even trace amounts of $\mathrm{Al}^{3+}$ in living cells could be noticeably detected by (SB-2). In this study, antimicrobial properties of Schiff base compounds were also carried out towards some selected bacteria species. This presented work provides a method for design, facile synthesis and application of effective fluorescence probes toward $\mathrm{Al}^{3+}$ ions in biological systems.
\end{abstract}

Keywords: Schiff base; Aluminum; Fluorescence; Cell imagine; Anti-bacterial

${ }^{1}$ Mevlüt BAYRAKCI (Orcid ID: 0000-0002-0416-2870), Bahar YILMAZ (Orcid ID: 0000-0002-6315-3018)
Karamanoğlu Mehmetbey Üniversitesi, Mühendislik Fakültesi, Biyomühendislik Bölümü, Karaman/Türkiye
*Sorumlu Yazar/Corresponding Author: Mevlut BAYRAKCI, mevlutbayrakci@gmail.com, mbayrakci@kmu.edu.tr
Geliş tarihi / Received: 23-01-2020
Kabul tarihi / Accepted: 21-04-2020 


\section{INTRODUCTION}

Aluminum is the third most abundant metal in the earth's crust and extensively used as raw material after iron in a wide range of heavy industry such as electric and electronic, information technology, cosmetic manufacturing, textile, building trade, medicine and environmental protections(Zhu et al., 2016; Lacowicz, 2002; Soni et al., 2001). Furthermore, aluminum has also an important role in biological applications system as biological transformation and enzyme-catalyzed reactions (Baxter et al., 2008).Recently, a large of medical research has been showed that using of excess amount of aluminum is harmful to human health and it causes some serious diseases such as osteoporosis, Parkinson's, osteomalacia and Alzheimer's (Walton, 2006; Altschuler, 1999; Sun et al., 2016; Gupta et al., 2012) and its level of concentration has a direct effect on human health. Therefore, the detection of aluminium is of great importance due to its potential hazard. However, the detection of aluminium ions have some complications because of the lack of spectroscopic identification, the strong hydration and poor coordination ability. Nevertheless, several analytical methods such as voltammetry, atomic-absorption spectroscopy (AAS), inductively coupled plasma emission spectrometry (ICP-AES), and potentiometric and spectrophotometric sensors have been used for low level detection of aluminum ions (Gupta et al., 2015; Shoora et al., 2015; Dillen et al., 1999). However, they have some limitations such as low selectivity, sophisticated expensive instruments, and longer period of response time in usage of these methods (Kim et al., 2012; Gupta et al., 2015).Among these techniques, the fluorescent method has most popular technique to determine the ionic species and have some advantages over other sophisticated analytical methods owing to its simplicity, low-cost analysis, high selectivity and sensitivity, naked-eye detection (Simona et al., 2016; Zhong et al., 2016). Thus, a more selective, sensitive and facile chemosensor is required to be synthesized and developed in medicinal, biological, and environmental applications with greater attention. For example, antibacterial activity is one of the most important topic in medicinal applications. In this field, Schiff base based molecules are extensively investigated with and without metal ions and some literature results reported that imine $(\mathrm{C}=\mathrm{N})$ modified molecules shows good antibacterial activities against many kinds of bacteria (Wang et al., 2011). The basic problem in the antibacterial treatment is to increase of microorganism resistance toward available drugs. Nitrofurantoin or Nifuroxazide, are example of Schiff base derivatives and these molecules are commonly applied in medicine as antibacterial agents (Sztanke et al., 2013). Although very limited literature study has been reported, some of them are still in progress. Therefore, the development of novel Schiff base type of organic compounds as a potential drug molecule is the center of some researches.

In the last decades, design and synthesis of high selective and sensitive fluorescent chemosensors have attracted great interest from current researchers due to the possible applications in different fields such as environmental, clinic and medicine (Santos-Figueroa et al., 2013; Janakipriya et al., 2016; Jeyanthi et al., 2013).To date, a limited number of chemosensor based Schiff base have been presented in literature for the detection of aluminum ions (Tian et al., 2015). The basic reason for the lesser development of aluminium chemosensors is owing to the poor coordination ability of aluminium with respect to the transition metal ions (Soroka et al., 1987). Based on this knowledge, herein, a series of Schiff base chemosensors SB-2, SB-3 and SB-4 which show an excellent selective and sensitive fluorescence enhancement response to $\mathrm{Al}^{3+}$ ions have been synthesized by Schiff-base condensation reaction from the corresponding ortho, meta and para aminophenol and 2,4-dihydroxybenzaldehyde as outlined in Scheme 1 and characterized by different spectroscopic techniques. To see the usability of these Schiff base derivatives as both potential antibacterial drug toward some selected bacteria and 
potential chemosensor for aluminum imagine in living cell line, some biological experiments such as antibacterial tests based disc diffusion and cell applications were also performed.

\section{MATERIALS AND METHODS}

\section{General}

2,4-dihydroxybenzaldehyde, ortho, meta and para aminophenol m-phenylenediamine and all the metal salts were of analytical grade and purchased from Sigma-Aldrich or Merck and was further used without any purification. ${ }^{1} \mathrm{H}$ NMR spectra was generated by Agilent Premium Compact spectrometer operating at $600 \mathrm{MHz}$. Bruker Vertex FT-IR spectrometer (ATR) was used for FT-IR spectra. UV-vis absorbance spectra were collected by a Shimadzu UV-1800 and the fluorescence measurements were recorded on Hitachi F-7100. Aqueous solutions were deionized through a Millipore Milli-Q Plus water purification system.

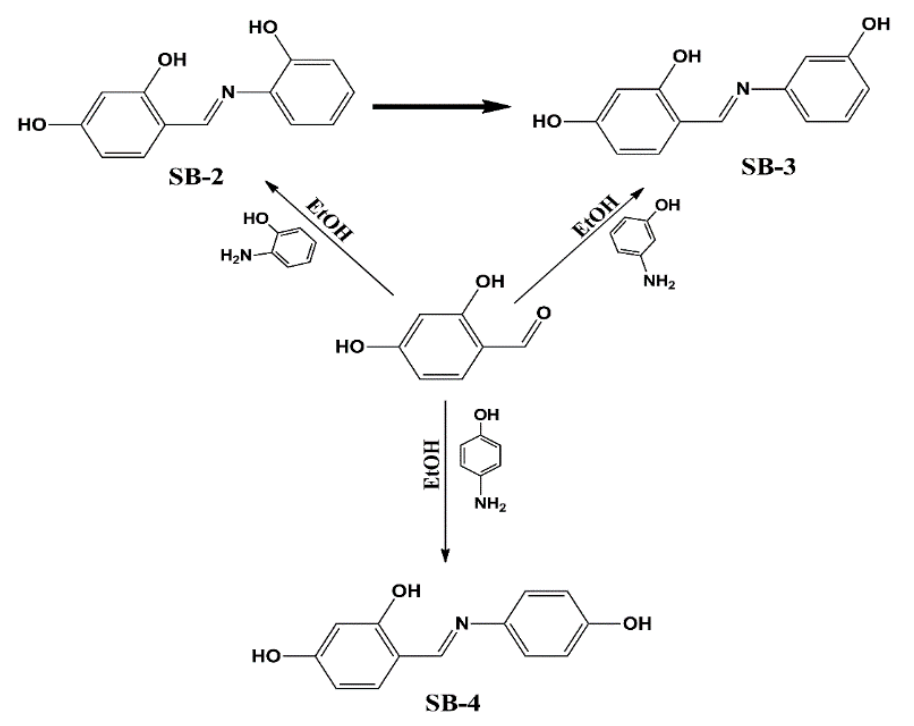

Scheme 1. Synthetic illustration for the preparation of optical probes based Schiff base

\section{Synthesis of Schiff bases (SB-2, SB-3 and SB-4)}

Schiff bases (SB-2, SB-3 and SB-4) were synthesized by following modified literature procedure (Gupta et al., 2015; Murtaza et al., 2016). Briefly, to a stirred solution of corresponding ortho, meta or para aminophenol compounds $(1.5 \mathrm{mmol})$ in $20 \mathrm{~mL}$ absolute ethanol (for SB-2, SB-3 and SB-4, respectively) was added $1.5 \mathrm{mmol}$ of 2,4-dihydroxybenzaldehyde; the reaction mixture was stirred under reflux for $18 \mathrm{~h}$. After completion of the reaction, excess amount of solvent was removed under reduced pressure and the solid residue was washed with $1 \mathrm{~N} \mathrm{HCl}$, brine and excess amount of water. The crude product was crystallized from $\mathrm{CH}_{2} \mathrm{Cl}_{2}-\mathrm{C}_{2} \mathrm{H}_{5} \mathrm{OH}$ (1:1) solvent system (Scheme 1).SB-2:Dark orange solid with 77\% yields, FT-IR (ATR cm $\left.{ }^{-1}\right): 1625$ (C=N stretching). ${ }^{1} \mathrm{H}$ NMR (600 MHz DMSO): $\delta 14.19$ (bs, 1H, OH) 10.12(s, 1H, OH), $9.61(\mathrm{~s}, 1 \mathrm{H}, \mathrm{OH}), 8.75(\mathrm{~s}, 1 \mathrm{H}, \mathrm{CH}=\mathrm{N}), 7.35$ (d, J=8.4 Hz, 1H, Ar-H), 7.27 (d, J= 7.8 Hz, 1H, Ar-H), 7.04 (m, 1H, Ar-H), 6.92 (d, J= 8.1 Hz, 1H, Ar-H), 6.83 (m, 1H, Ar-H), 6.33 (d, $J=8.4 \mathrm{~Hz}, 1 \mathrm{H}, \mathrm{Ar}-\mathrm{H}), 6.22$ (s, $1 \mathrm{H}, \mathrm{Ar}-\mathrm{H})$. Anal. calcd. For $\mathrm{C}_{13} \mathrm{H}_{11} \mathrm{O}_{3} \mathrm{~N}$ : C, 68.11; H, 4.84; N, 6.11. Found: C, 68.09; H, 4.90; N, 6.19\%.SB-3: Dark yellow solid with 70\% yields,FT-IR (ATR cm $\left.{ }^{-1}\right): 1621$ (C=N stretching). ${ }^{1} \mathrm{H}$ NMR (600 MHz DMSO): $\delta 14.18$ (bs, 1H, OH) $10.12(\mathrm{~s}, 1 \mathrm{H}, \mathrm{OH}), 9.63$ (s, 1H, $\mathrm{OH}), 8.76(\mathrm{~s}, 1 \mathrm{H}, \mathrm{CH}=\mathrm{N}), 7.33(\mathrm{~d}, J=8.4 \mathrm{~Hz}, 1 \mathrm{H}, \mathrm{Ar}-\mathrm{H}), 7.25(\mathrm{~d}, J=7.8 \mathrm{~Hz}, 1 \mathrm{H}, \mathrm{Ar}-\mathrm{H}), 7.03(\mathrm{~m}, 1 \mathrm{H}$, Ar-H), 6.91 (d, J=8.1 Hz, 1H, Ar-H), 6.84 (m, 1H, Ar-H), 6.33 (d, J=8.4 Hz, 1H, Ar-H), 6.21 (s, 1H, Ar-H). Anal. calcd. For $\mathrm{C}_{13} \mathrm{H}_{11} \mathrm{O}_{3} \mathrm{~N}$ : C, 68.11; H, 4.84; N, 6.11. Found: C, 68.03; H, 4.80; N, 6.07\%.SB4: Dark yellowish solid with $73 \%$ yields,FT-IR $\left(A T R \mathrm{~cm}^{-1}\right): 1619\left(\mathrm{C}=\mathrm{N}\right.$ stretching). ${ }^{1} \mathrm{H} \mathrm{NMR}(600 \mathrm{MHz}$ 
DMSO): $\delta 14.18(\mathrm{bs}, 1 \mathrm{H}, \mathrm{OH}) 10.12(\mathrm{~s}, 1 \mathrm{H}, \mathrm{OH}), 9.66(\mathrm{~s}, 1 \mathrm{H}, \mathrm{OH}), 8.77(\mathrm{~s}, 1 \mathrm{H}, \mathrm{CH}=\mathrm{N}), 7.34(\mathrm{~d}, J=8.4$ Hz, 1H, Ar-H), 7.27 (d, J= 7.8 Hz, 1H, Ar-H), 7.08 (t, 1H, Ar-H), 6.93 (d, J=8.1 Hz, 1H, Ar-H), 6.83 $(\mathrm{m}, 1 \mathrm{H}, \mathrm{Ar}-\mathrm{H}), 6.34$ (d, J=8.4 Hz, 1H, Ar-H), 6.21 (s, $1 \mathrm{H}, \mathrm{Ar}-\mathrm{H})$. Anal. calcd. For $\mathrm{C}_{13} \mathrm{H}_{11} \mathrm{O} 3 \mathrm{~N}$ : C, 68.11; H, 4.84; N, 6.11. Found: C, 68.03; H, 4.88; N, 6.15\%.

\section{Uv-vis and fluorescence studies}

The stock solutions of SB-2, SB-3, and SB-4 $(1 \mathrm{mM})$, the guest nitrate salts of cations $\left(\mathrm{Li}^{+}, \mathrm{Na}^{+}\right.$, $\mathrm{Ag}^{+}, \mathrm{Ca}^{2+}, \mathrm{Ba}^{2+}, \mathrm{Co}^{2+}, \mathrm{Cs}^{+}, \mathrm{Cu}^{2+}, \mathrm{Mg}^{2+}, \mathrm{Hg}^{2+}, \mathrm{Mn}^{2+}, \mathrm{Pb}^{2+}, \mathrm{Ni}^{2+}, \mathrm{Sr}^{2+}, \mathrm{Zn}^{2+}$ and $\left.\mathrm{Al}^{3+}\right)(1 \mathrm{mM})$ in DMF were prepared. In spectrophotometric experiments, the volume of studied solutions was adjusted as 2.0 $\mathrm{mL}$. Titration experiments were performed by addition of corresponding amount of cation solutions to a DMF solution of SB-2, SB-3, and SB-4. All emission spectra were obtained at room temperature under the excitation of $400 \mathrm{~nm}$. The absorption spectra of SB-2, SB-3, and SB-4 in the presence and absence of cations were recorded in the range of $200-600 \mathrm{~nm}$ in a UV-Vis spectrophotometer. The solutions were scanned $(1200 \mathrm{~nm} / \mathrm{min})$ with 400 watt of PMT voltage in a spectrofluorometer with the range of 430-750 $\mathrm{nm}$. The widths of the slit for the both excitation and emission were adjusted at $10 \mathrm{~nm}$. The fluorescence intensity at $500 \mathrm{~nm}$ was determined under the excitation at the wavelength of $400 \mathrm{~nm}$.

\section{Biological applications}

The living MCF7 cells were provided by ATCC (American Type Culture Collection, Rockville, MD, USA). MCF7 cells were incubated with $10 \mu \mathrm{M}$ of $\mathrm{Al}^{3+}$ ions in the culture medium at $37^{\circ} \mathrm{C}$ for $1 \mathrm{~h}$ and washed with phosphate buffered saline (PBS)followed by the addition of $20 \mu \mathrm{M} \mathrm{SB-2}$. Bright field and fluorescent images were taken from Leica DM3000 fluorescence microscopy (FM) (Cicekbilek et al., 2019). Antimicrobial susceptibility was tested by the disk diffusion method on LB and NB agar, according to the guidelines of the National Committee for Clinical Laboratory Standards (NCCLS) (Fiebelkorn et al., 2013). Briefly, disks containing Schiff bases SB-2, SB-3, and/orSB-4 incubated at 37 ${ }^{\circ} \mathrm{C}$ for $24 \mathrm{~h}$ were placed on NB agar plates for gram positive bacteria $B$. subtilis or on LB agar gram negative bacteria for $E$. coli, respectively. After this time, resistance or susceptibility behaviors of $B$. subtilis or E. coli towards Schiff bases SB-2, SB-3, and/or SB-4was monitored by measuring of the obtained inhibition zone diameters at different incubation temperatures (Tahriri et al., 2017).
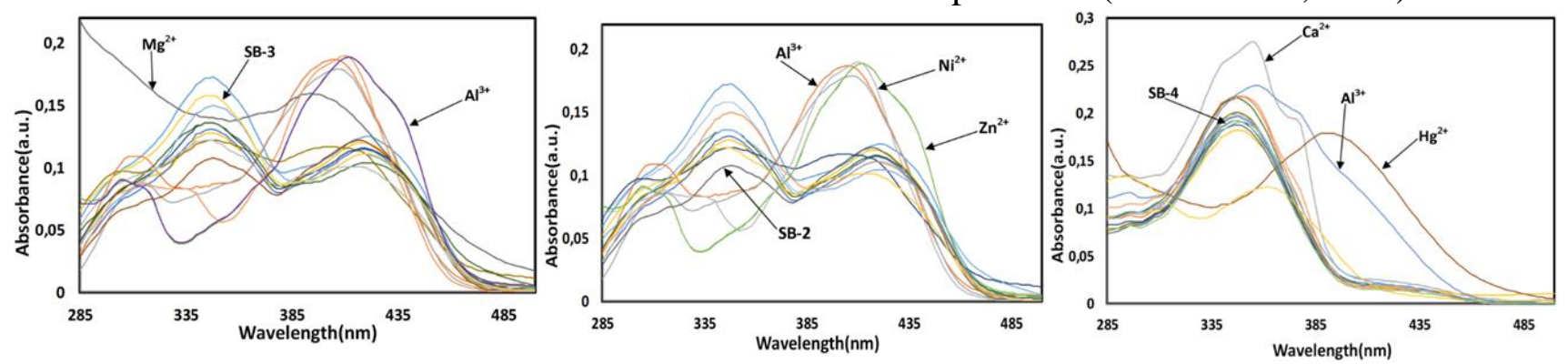

Figure 1. UV-Vis absorption spectra of compounds SB-2, SB-3 and SB-4 (10 $\mu \mathrm{M})$ in the absence and presence of different metal ions (20 equiv.) such as $\mathrm{Li}^{+}, \mathrm{Na}^{+}, \mathrm{Ag}^{+}, \mathrm{Ca}^{2+}, \mathrm{Ba}^{2+}, \mathrm{Co}^{2+}, \mathrm{Cs}^{+}, \mathrm{Cu}^{2+}, \mathrm{Mg}^{2+}, \mathrm{Hg}^{2+}, \mathrm{Mn}^{2+}, \mathrm{Pb}^{2+}, \mathrm{Ni}^{2+}, \mathrm{Sr}^{2+}, \mathrm{Zn}^{2+}$ and $\mathrm{Al}^{3+}$ at room temperature.

\section{RESULTS AND DISCUSSION}

\section{UV-vis absorption analysis}

The UV-vis absorption spectrum of the Schiff bases SB-2, SB-3, and SB-4towards various metal cations was explored in dimethylformamide (DMF) solution $(10 \mu \mathrm{M})$ in the presence of 20 equiv. of metal cations. As seen in Figure 1, the absorption spectrum of SB-2, and SB-3, exhibited two broad absorption bands at around $348 \mathrm{~nm}$ and $414 \mathrm{~nm}$ attributable to $\pi-\pi^{*}$ transition of the imine moiety. The 
small changes for the position of absorption bands was observed after the addition of $\mathrm{Al}^{3+}, \mathrm{Ni}^{2+}$ and $\mathrm{Zn}^{2+}$ owing to the imine nitrogen $(\mathrm{CH}=\mathrm{N})$ was involved in coordination with metal ion. However, considerable changes in the absorption spectra of the SB-2, and SB-3 were not observed over other metal ions. Similar changes in the spectra of SB-4 were observed for the $\mathrm{Hg}^{2+}, \mathrm{Ca}^{2+}$ and $\mathrm{Al}^{3+}$. Considering these changes, powerful hyperchromic changes was only seen for SB-2, and SB-3 at around $348 \mathrm{~nm}$ and $414 \mathrm{~nm}$ with $\mathrm{Al}^{3+}$ ions.
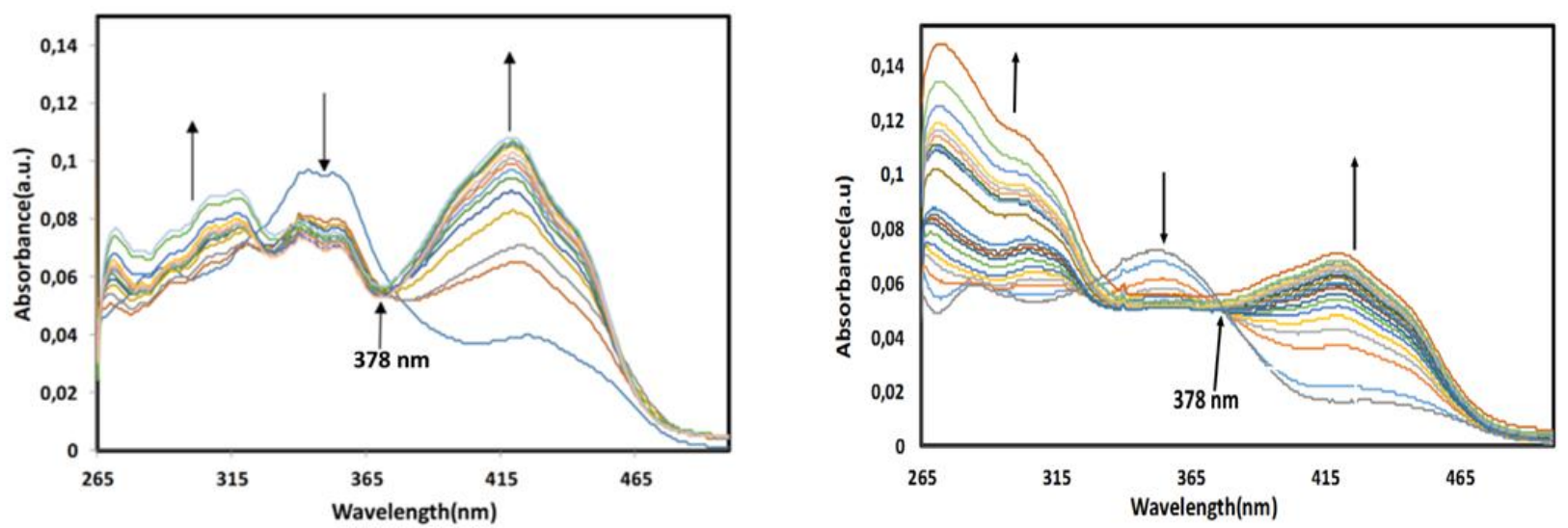

Figure 2. UV-Vis absorption spectra of compounds SB-2 and SB-3 $(10 \mu \mathrm{M})$, respectively, upon the titration of $\mathrm{Al}^{3+}$ (from 0 to 2 equiv.) at room temperature.

The binding properties of SB-2 and SB-3 with $\mathrm{Al}^{3+}$ ions were studied by UV-vis titration in DMF solution (Figure 2).Upon addition of increasing amounts of $\mathrm{Al}^{3+}$ (0.0 to 2.0 equiv.), absorption bands of SB-2 appeared at $272 \mathrm{~nm}$ and $420 \mathrm{~nm}$ was gradually enhanced with increasing concentration of $\mathrm{Al}^{3+}$, while the intensities of absorption at $350 \mathrm{~nm}$ were decreased. During the titration of SB-2 with $\mathrm{Al}^{3+}$, the clear isosbestic point were observed at $378 \mathrm{~nm}$ which means that an equilibrium and interaction generated between SB-2 and $\mathrm{Al}^{3+}$. These observations supported the definite conversion of SB-2 to the corresponding aluminum metal complex having a precise stoichiometric ratio between $\mathbf{S B}-2$ and $\mathrm{Al}^{3+}$ formed in solution. Subsequently, the further addition of $\mathrm{Al}^{3+}$ did not change the UV-vis spectra of SB2. The titration configuration of SB-2 with $\mathrm{Al}^{3+}$ shown indicated 1 equiv. of $\mathrm{Al}^{3+}$ reacting with same equiv. ofSB-2 could quickly reached an equilibrium, showing complex formation between SB-2 and $\mathbf{A l}^{\mathbf{3 +}}$ with 1:1 stoichiometry. Furthermore, same results were also observed for complex structure of SB$\mathbf{3}$ with $\mathrm{Al}^{3+}$. Fluorescence emission studies was performed for getting and interpreting the more accurate and precise spectrophotometric results since absorption spectroscopy was complementary part of emission spectroscopy.
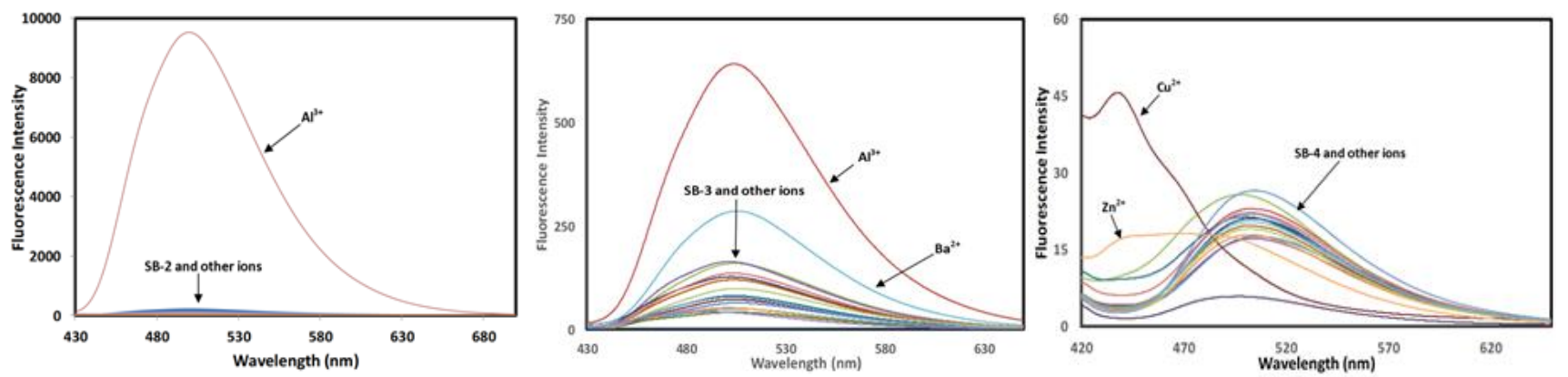

Figure 4. Fluorescence emission spectra (at $500 \mathrm{~nm}$ ) of compounds SB-2, SB-3 and SB-4 $(10 \mu \mathrm{M})$ in DMF in the presence of different metal ions (20 equiv.) such $\mathrm{Li}^{+}, \mathrm{Na}^{+}, \mathrm{Ag}^{+}, \mathrm{Ca}^{2+}, \mathrm{Ba}^{2+}, \mathrm{Co}^{2+}, \mathrm{Cs}^{+}, \mathrm{Cu}^{2+}, \mathrm{Mg}^{2+}, \mathrm{Hg}^{2+}, \mathrm{Mn}^{2+}$, $\mathrm{Pb}^{2+}, \mathrm{Ni}^{2+}, \mathrm{Sr}^{2+}, \mathrm{Zn}^{2+}$ and $\mathrm{Al}^{3+}$. ( $\left.\lambda_{\mathrm{ex}}=400 \mathrm{~nm}\right)$. 


\section{Fluorescence emission analysis}

High selectivity is necessary to define the excellent chemosensor. Therefore, to evidence the usability of the synthesized Schiff bases SB-2, SB-3, and SB-4 as a selective sensor, the fluorescence behavior of SB-2, SB-3, and SB-4was investigated by using Hitachi F-7100Spectrofluorometer upon the addition of selected metal ions such as $\mathrm{Li}^{+}, \mathrm{Na}^{+}, \mathrm{Ag}^{+}, \mathrm{Ca}^{2+}, \mathrm{Ba}^{2+}, \mathrm{Co}^{2+}, \mathrm{Cs}^{+}, \mathrm{Cu}^{2+}, \mathrm{Mg}^{2+}, \mathrm{Hg}^{2+}, \mathrm{Mn}^{2+}$, $\mathrm{Pb}^{2+}, \mathrm{Ni}^{2+}, \mathrm{Sr}^{2+}, \mathrm{Zn}^{2+}$ and $\mathrm{Al}^{3+}$.Schiff base SB-2, SB-3, and SB-4did not show any considerable emission band alone at $500 \mathrm{~nm}$ when the excitation wavelength was at $400 \mathrm{~nm}$. After addition of metal ions such as $\mathrm{Li}^{+}, \mathrm{Na}^{+}, \mathrm{Ag}^{+}, \mathrm{Ca}^{2+}, \mathrm{Ba}^{2+}, \mathrm{Co}^{2+}, \mathrm{Cs}^{+}, \mathrm{Cu}^{2+}, \mathrm{Mg}^{2+}, \mathrm{Hg}^{2+}, \mathrm{Mn}^{2+}, \mathrm{Pb}^{2+}, \mathrm{Ni}^{2+}, \mathrm{Sr}^{2+}$ and $\mathrm{Zn}^{2+}$ (Figure 4), Schiff baseSB-2, SB-3, and SB-4 did not still demonstrate any significant fluorescent response. However, upon addition of $\mathrm{Al}^{3+}$ ions, only Schiff base SB-2 and SB-3 exhibited excellent response with more than 335-fold and 11-fold fluorescent enhancement. This fascinating increase in fluorescence intensity of SB-2demonstrated that selective and excellent 'off-on' type fluorescent sensor behavior of SB-2had occurred toward $\mathrm{Al}^{3+}$.
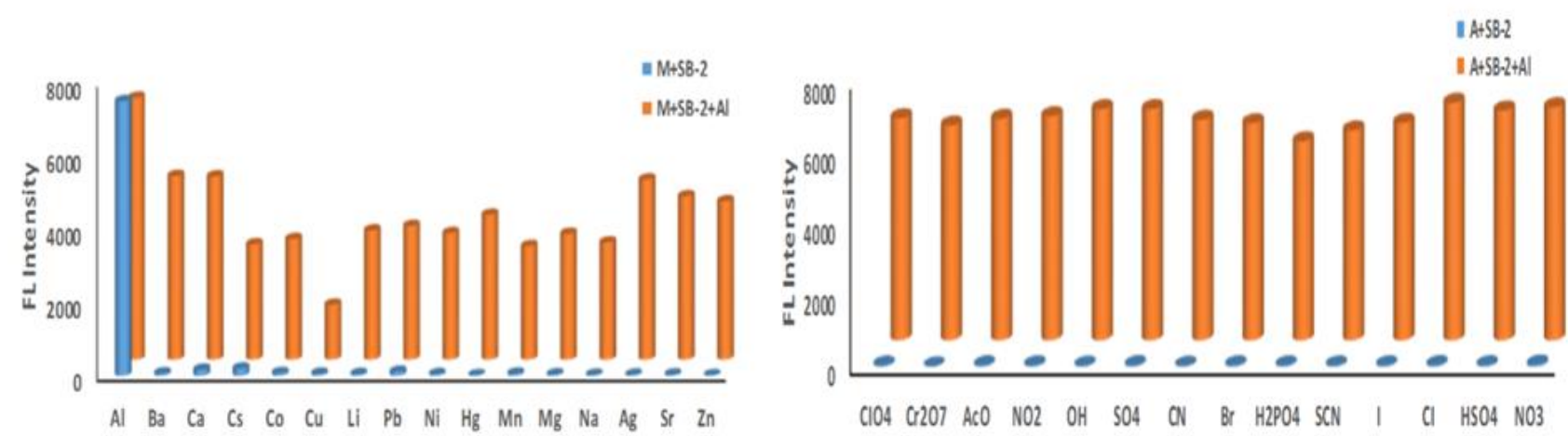

Figure 5. Fluorescence intensity of SB-2 and its complexation with $\mathrm{Al}^{3+}$ in the presence of various cations or anions. $\left(\lambda_{\mathrm{ex}}=400 \mathrm{~nm}\right)$.

For the investigation of the selectivity performance of SB-2 or SB-3 toward $\mathrm{Al}^{3+}$ ions, some competing experiments was carried out by using metal ions. Interferences of metal cations were investigated by treating SB-2 or SB-3 with 20 equiv. of $\mathrm{Al}^{3+}$ in the presence of equal to competing metal cations $\left(\mathrm{Li}^{+}, \mathrm{Na}^{+}, \mathrm{Ag}^{+}, \mathrm{Ca}^{2+}, \mathrm{Ba}^{2+}, \mathrm{Co}^{2+}, \mathrm{Cs}^{+}, \mathrm{Cu}^{2+}, \mathrm{Mg}^{2+}, \mathrm{Hg}^{2+}, \mathrm{Mn}^{2+}, \mathrm{Pb}^{2+}, \mathrm{Ni}^{2+}, \mathrm{Sr}^{2+}\right.$ and $\mathrm{Zn}^{2+}$ ). As shown in Figure 5, it was observed that fluorescence response of compounds $\mathbf{S B - 2}$ or $\mathbf{S B}-\mathbf{3}$ for $\mathrm{Al}^{3+}$ was not affected by addition of competing metal ions or some selected anions considerably. But the relatively

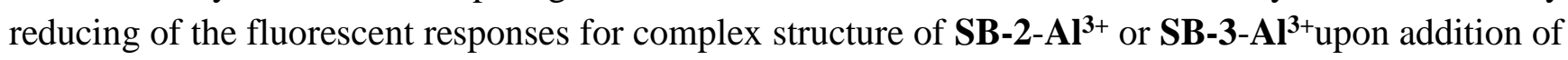
some studied metal ions was also observed. Despite addition of these metal ions, it was seen that fluorescence responses of SB-2 and SB-3 toward $\mathrm{Al}^{3+}$ ions could be easily and clearly detectable under UV-light by naked-eye. Both SB-2 and SB-3 still have an efficient "turn-on" rate for the detection of $\mathrm{Al}^{3+}$. From the competition results, it was seen that Schiff basesSB-2 and SB-3 as a probe had high selectivity and specificity toward $\mathrm{Al}^{3+}$ over other ions such as $\mathrm{Li}^{+}, \mathrm{Na}^{+}, \mathrm{Ag}^{+}, \mathrm{Ca}^{2+}, \mathrm{Ba}^{2+}, \mathrm{Co}^{2+}, \mathrm{Cs}^{+}, \mathrm{Cu}^{2+}$, $\mathrm{Mg}^{2+}, \mathrm{Hg}^{2+}, \mathrm{Mn}^{2+}, \mathrm{Pb}^{2+}, \mathrm{Ni}^{2+}, \mathrm{Sr}^{2+}$, and $\mathrm{Zn}^{2+}$. AmongSB-2 solutions with and without metal cations excited at $400 \mathrm{~nm}$, only the SB-2 solutions mixed with $\mathrm{Al}^{3+}$ ions showed an extraordinary color change from toneless to brilliant fluorescent blue and this change was easily detected by the naked eye under UV light(Figure 6).

The observed fluorescence enhancement can be explained by the blocking the photoinduced electron transfer (PET) process when SB-2 is bound with $\mathrm{Al}^{3+}$ (Ding et al., 2015). The lone pair electrons of azomethine $(\mathrm{CH}=\mathrm{N})$ unit of probe SB-2delocalize (un-blocking of PET) to the two phenyl rings in the Schiff base structure and quenches the fluorescence intensity. After addition of $\mathrm{Al}^{3+}$, this lone pair electron of imine group is perturbed by the coordination of $\mathrm{Al}^{3+}$ and this interaction give rise to an 
increase in fluorescence intensity. This situation proposes that the photo induced electron transfer (PET) is the favorable mechanism to explain "off-on" type of fluorescence for SB-2 after binding to $\mathrm{Al}^{3+}$.

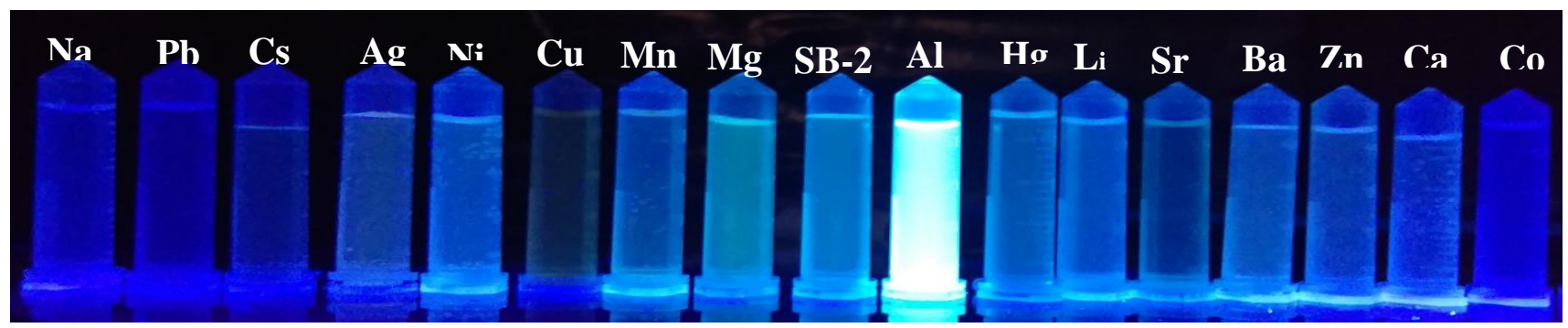

Figure 6. Images showing the corresponding fluorescence color changes of SB-2 with and without metal cations (20 equiv.) under UV light.

To further examine the sensing properties of SB-2 and SB-3, sensitivity of SB-2 and SB-3 as a probe toward $\mathrm{Al}^{3+}$ ions was investigated by the fluorescence titration experiments by increasing concentration of $\mathrm{Al}^{3+}$ ions (0-20 equiv.) at $500 \mathrm{~nm}$ (Figure 7) and the detection limit of $\mathrm{Al}^{3+}$ was estimated based on the fluorescence titration profile. The detection limit of SB-2 in recognizing $\mathrm{Al}^{3+}$ was found to be $6.45 \cdot 10^{-7} \mathrm{M}$ which was lower than some presented $\mathrm{Al}^{3+}$ selective chemosensors (Ding et al., 2015, Tian et al., 2015; Zhou et al., 2015). This result has shown that this sensor could be used for both detection and monitoring of sub-micromolar concentration of aluminum ions in biological and environmental systems.
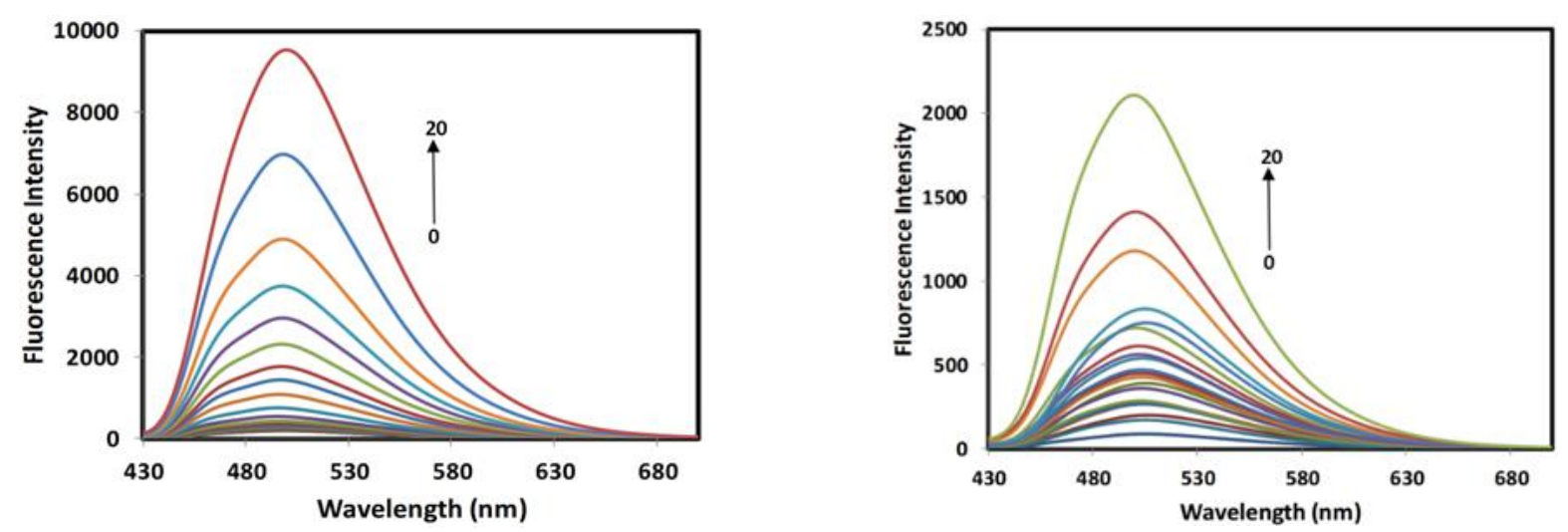

Figure 7. Fluorescence titration spectra of SB-2and SB-3, respectively, upon addition of $\mathrm{Al}^{3+}$ (from 0 to 20 equiv.) with an excitation of $400 \mathrm{~nm}$, and an emission of $500 \mathrm{~nm}$.

The molar ratio of the coordination between SB-2 and $\mathrm{Al}^{3+}$ was studied by the Job's plot method (Job, 1928) as shown in Figure 8. In this method, each experiment carried out with different concentrations of SB-2 and $\mathrm{Al}^{3+}$ ions with maintaining the total concentration at $20 \mu \mathrm{M}$. The plot obtained by measuring the fluorescence intensity at $500 \mathrm{~nm}$ for nine experiments with molar fraction of SB-2 (0.1 to 0.9). The maximum fluorescence intensity at $500 \mathrm{~nm}$ was observed when the molar fraction was 0.5 . This data showed that 1 mole of SB-2 probe and $\mathrm{Al}^{3+}$ participated in the complex formation and binding mode was determined as 1:1 stoichiometry. Furthermore, the binding constant of the probe SB2 with $\mathrm{Al}^{3+}$ were calculated by the Benesi-Hildebrand method (Benesi and Hildebrand, 1949). From curve fitting of fluorescence intensity of probe SB-2 against the reciprocal of the $\mathrm{Al}^{3+}$ concentration, this plot yielded a linear fit as seen in Figure9. The value of the binding constant was calculated as $2.8 \cdot 10^{5}$ $\mathrm{M}^{-1}$ for probe SB-2 from this equation. In addition, the linear plot also proved the 1:1 complexation 
behavior of SB-2to $\mathrm{Al}^{3+}$. Because, if a 1:1 metal-probe complex is formed between receptor and metal ions, Benesi-Hildebrand plot should be linear (Benesi and Hildebrand, 1949).
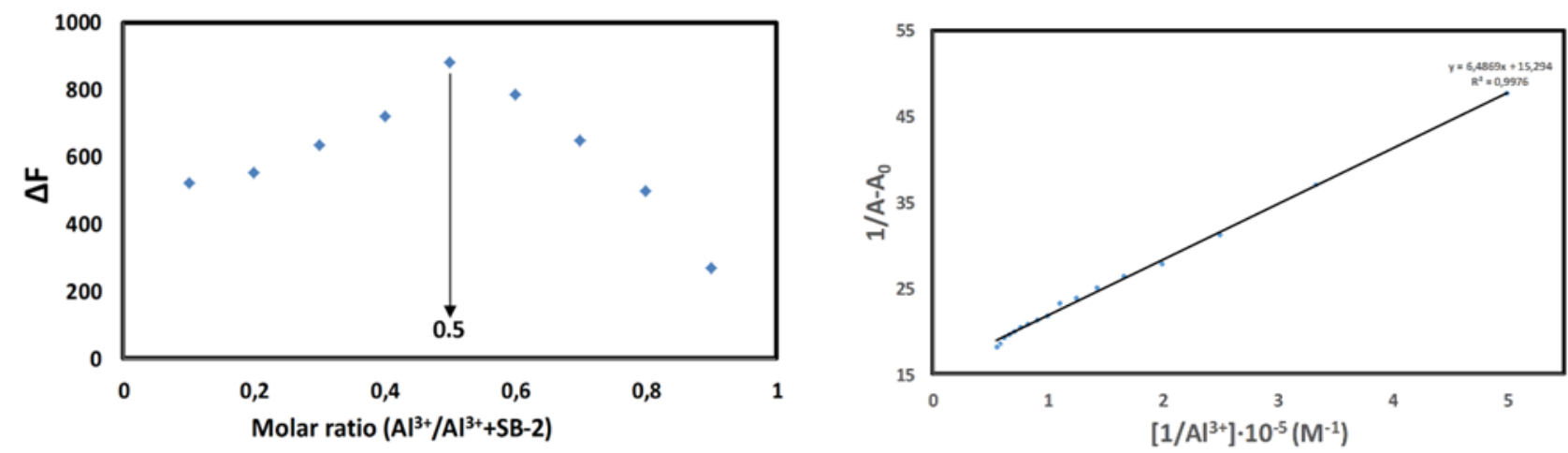

Figure8. Job's plot and Benesi-Hildebrant plot for determining the complexation behavior of SB-2 to $\mathrm{Al}^{3+}$ in DMF.

In related to stoichiometry, the binding site participated in complexation was clarified by FT-IR and ${ }^{1} \mathrm{H}$ NMR titration experiments along with stoichiometry confirmation as presented in Figure 9 and 10.The IR spectra of SB-2 and SB-2-Al ${ }^{3+}$ showed that the characteristics frequencies of SB-2 with different stoichiometric ratio of $\mathrm{Al}^{3+}$ exhibited significant changes as compared with those of the $\mathbf{S B - 2}$ without $\mathrm{Al}^{3+}$. The IR spectra of the free SB-2 showed the absence of bands at around 1735 and $3300 \mathrm{~cm}^{-}$ ${ }^{1}$ attributable to the carbonyl $v(\mathrm{C}=\mathrm{O})$ and $v\left(\mathrm{NH}_{2}\right)$ stretching vibrations and a clear strong new band at around $1625 \mathrm{~cm}^{-1}$ due to azomethine $v(\mathrm{HC}=\mathrm{N})$ linkage. All these existing and disappearing signals in FT-IR indicated that amino and aldehyde groups in starting reactants (Scheme 1) were converted into the SB-2 and synthesis of the SB-2 was successfully carried out. The comparison of FT-IR spectra of free SB-2 and its $\mathrm{Al}^{3+}$ complex (Figure 2) demonstrated that SB-2 probe was principally coordinated to the $\mathrm{Al}^{3+}$ ion. The strong band appearing at around $1625 \mathrm{~cm}^{-1}$ due to azomethine group shifted to a lower frequency at $1589 \mathrm{~cm}^{-1}$ in $\mathrm{Al}^{3+}$ complex, indicating participation of azomethine group in the complexation with the $\mathrm{Al}^{3+}$ ion.

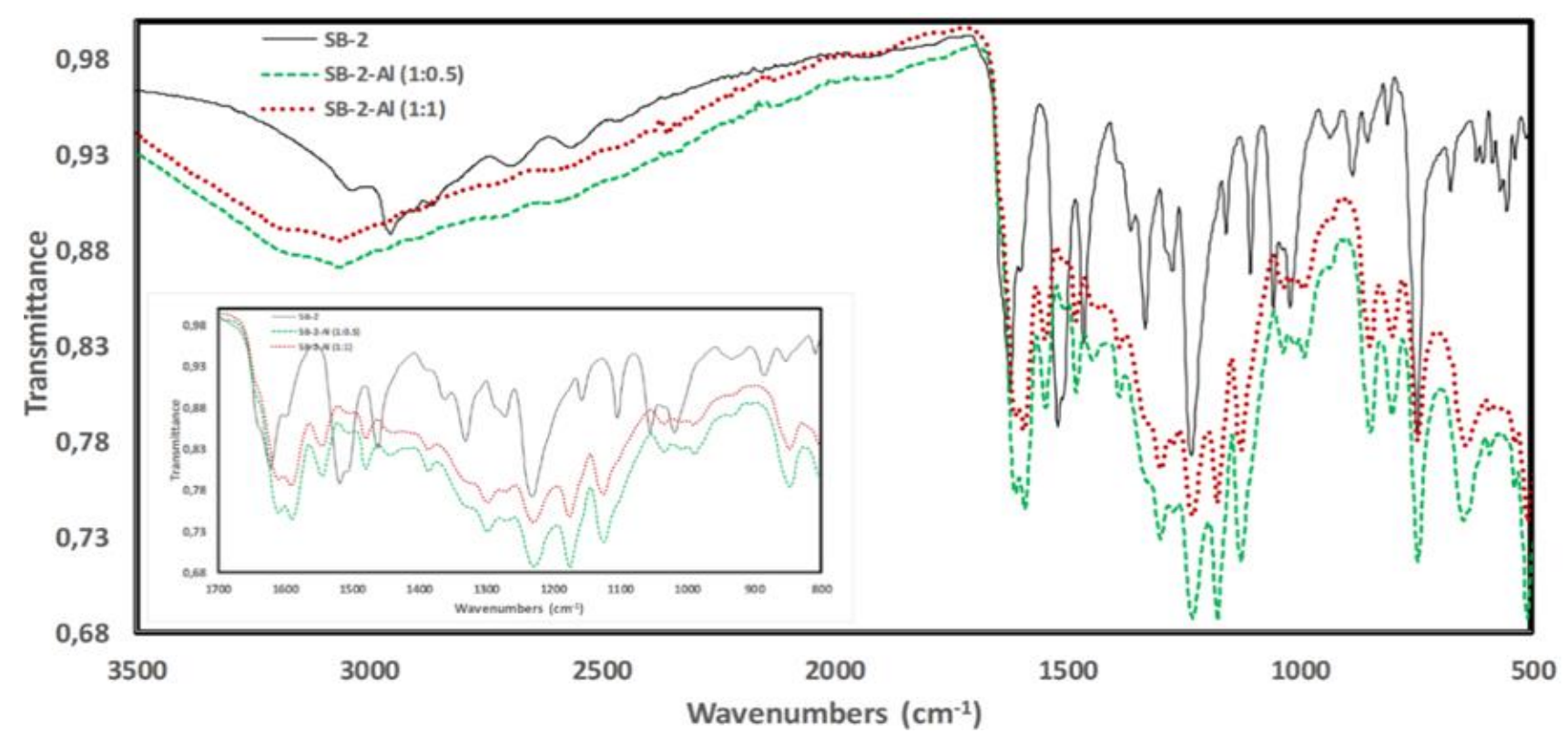

Figure 9. The FT-IR spectra data of SB-2 in presence of different amount of $\mathrm{Al}^{3+}$. 
To better understand the complexation between the probe SB-2 and $\mathrm{Al}^{3+},{ }^{1} \mathrm{HNMR}$ titration experiments of SB-2 in DMSO- $d_{6}$ were examined by addition of varied equiv. of $\mathrm{Al}^{3+}$. As seen in Figure10, three phenolic -OH signals belonging to SB-2was observed at around 9.61,10.12 and 14.19 ppm which showed that it was very acidic due to the intramolecular hydrogen bonding (Figure11). While the phenolic $\mathrm{OH}$ proton at $14.19 \mathrm{ppm}$ disappeared when added of 0.5 and 1.0 equiv. of $\mathrm{Al}^{3+}$ to $\mathbf{S B}$ 2solution, the other signal at around 10.12and $9.61 \mathrm{ppm}$ shifted to downfield (Keskin and Bayrakci, 2019). Also, the imine ( $\mathrm{CH}=\mathrm{N})$ proton of SB-2 at $8.76 \mathrm{ppm}$ was slightly shifted downfield. This shift for the imine proton was probably due to de-shielding of the azomethine group after coordination of SB2 with $\mathrm{Al}^{3+}$. All these shifting and/or disappearing of signals showed that both phenolic $\mathrm{OH}$ group located in ortho position and imine group of SB-2were efficient on complex formation between SB-2 and $\mathrm{Al}^{3+}$.

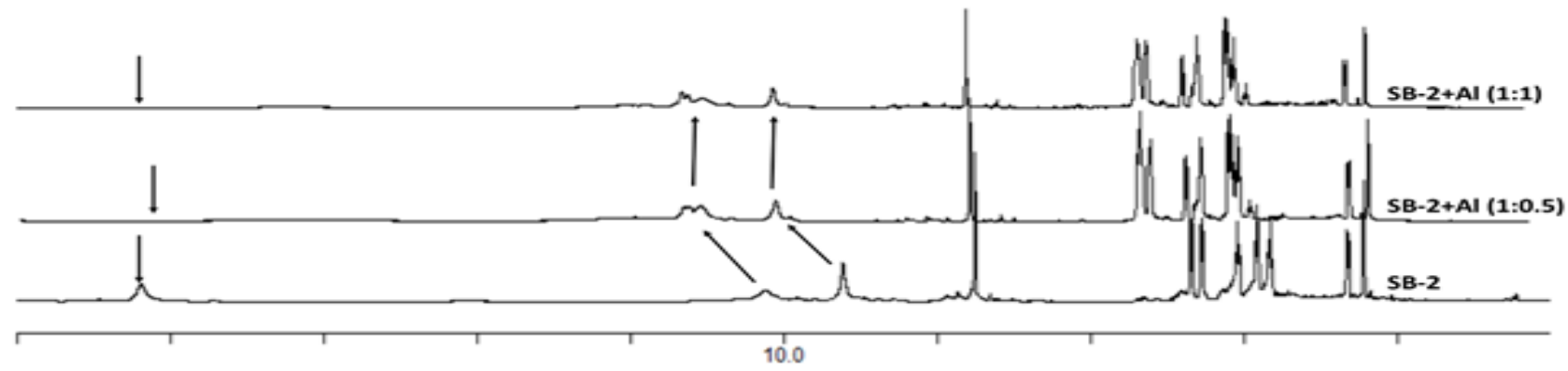

Figure 10. ${ }^{1} \mathrm{H}$ NMR spectra of SB-2 in DMSO- $d_{6}$ at $25^{\circ} \mathrm{C}$ and the corresponding changes after the addition of aluminum nitrate.

\section{Biological Applications}

SB-2 was successfully applied for imaging of $\mathrm{Al}^{3+}$ ions in human breast cancer cells, MCF7 under fluorescence microscope. Cells treated with SB-2, without any $\mathrm{Al}^{3+}$ and treated with $\mathrm{Al}^{3+}$ were used as controls. When MCF7 cells were incubated with SB-2 $(20 \mu \mathrm{M})$, it was not seen any fluorescence response. However, after addition of $\mathrm{Al}^{3+}$ ions, a brilliant red fluorescence was sighted in the MCF7 cells (Figure 11). Merged images of fluorescence and bright-field showed that fluorescence signals were detected in the intra-cellular zone (Kim et al., 2007), showing the distribution of $\mathrm{Al}^{3+}$ and cell membrane permeabilities of SB-2 molecules. On the other hand, Figure12 indicated that SB-2 could stain $\mathrm{Al}^{3+}$ ions in living cells without any harm (cells remain alive even after several hours of exposure to $20 \mu \mathrm{M}$ SB2), making it useful to monitor $\mathrm{Al}^{3+}$ in biological systems.

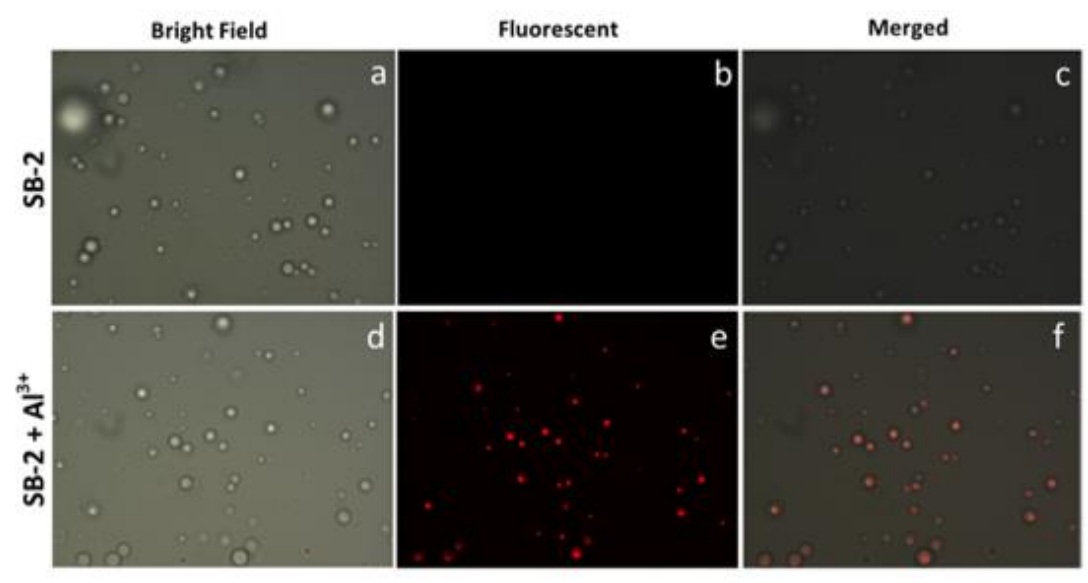

Figure 11. Fluorescence images of $\mathrm{Al}^{3+}$ using probe $\mathbf{S B}-2$ in MCF7 cells: (a) bright field imageof MCF7 cells treated with probe SB-2; (b) fluorescence image of MCF7 cells with probe SB-2; (c) merged image of (a) and (b); (d) bright field image of MCF7 cells treated with probe SB-2 and $\mathrm{Al}^{3+}$; (e) fluorescence image of MCF7 cells treated with probe SB-2 and $\mathrm{Al}^{3+}$ (d); (f) merged image of (d) and (e). 
To further demonstrate the practical biological application of SB-2 and other Schiff bases SB-3 and SB-4, antimicrobial properties of them towards human pathogenic gram positive and gram-negative bacteria were evaluated by measuring the zone of inhibition in disc diffusion method. In Figure 12, measured zones of inhibition for the Schiff bases ranged from 2.0 to $2.2 \mathrm{~cm}$ for SB-2, and SB-3, and 1.9 to $2.0 \mathrm{~cm}$ for SB-4 against gram positive bacteria $B$. subtilis. In addition, the zones of inhibition for the Schiff bases ranged from 2.0 to $2.1 \mathrm{~cm}$ for SB-2, 2.0 to $2.2 \mathrm{~cm}$ for SB-3, and 2.1 to $2.3 \mathrm{~cm}$ for SB-4 toward gram negative bacteria $E$. coli. Based on zones of inhibition results, Schiff base based compounds SB-2, SB-3 and SB-4 showed better activity against both gram positive and gram-negative bacteria lines. Obtained antimicrobial data for SB-2, SB-3 and SB-4 is not surprising. Because, it is well-known that the azomethine linkage $(-\mathrm{C}=\mathrm{N}-)$ in the Schiff base structure indicates widespread biological activities due to increased lipo-solubility of the Schiff base molecules in crossing cell membrane of the microorganism by blocking the protein synthesis which inhibits further growth of the organisms (Neelakantan et al., 2008).

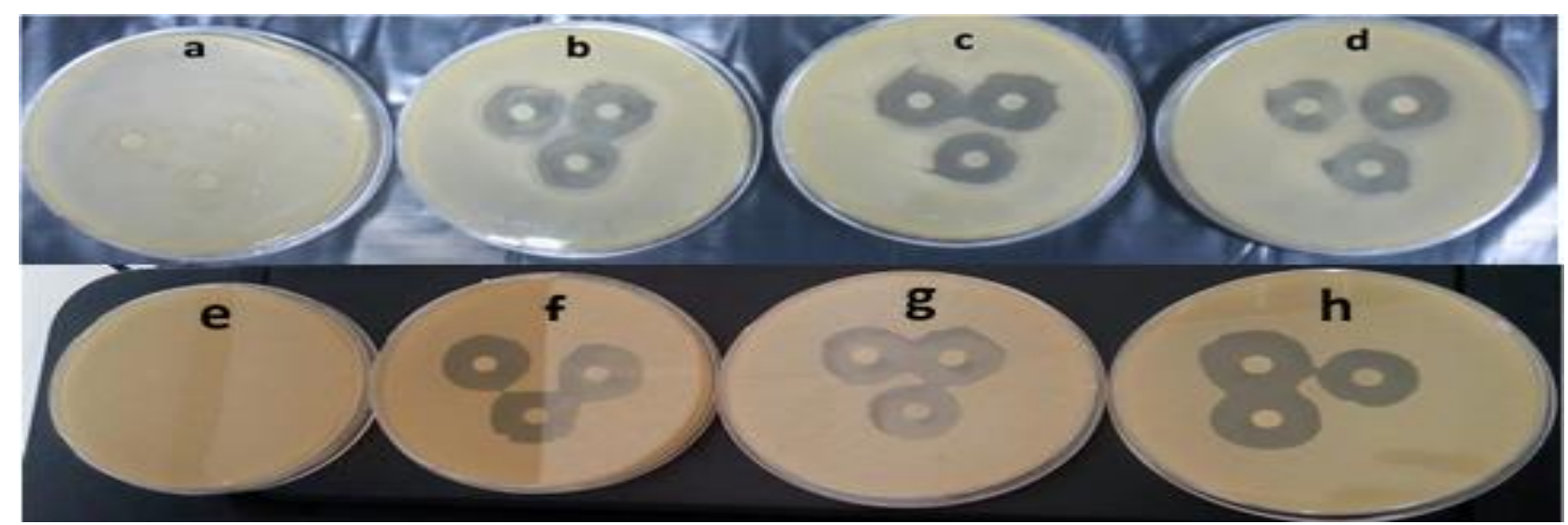

Figure 12. Photograph of antibacterial test of the Schiff bases SB-2, SB-3 and SB-4 after $24 \mathrm{~h}$ of incubation at 37 ${ }^{\circ}$ C: (a) control and E. coli; (b) SB-2 and E. coli; (c) SB-3 and E. coli; (d) SB-4 and E. coli; (e) control and B. subtilis; (f) SB-2 and B. subtilis; (g) SB-3 and B. subtilis; and (h) SB-4 and B. subtilis.

\section{CONCLUSION}

In conclusion, detection of $\mathrm{Al}^{3+}$ ions with highly selective and sensitive by a very simple and lowcost fluorescence sensor (SB-2) were presented successfully. SB-2 showed high sensitivity with the detection limit at around $6.45 \cdot 10^{-7} \mathrm{M}$ in the micromolar scale. The predicted configuration of the (SB2) $-\mathrm{Al}^{3+}$ complex formation was well-characterized to be $1: 1$ by spectroscopic analyses. Beyond that, (SB-2) was utilized to detect sensitively the $\mathrm{Al}^{3+}$ ions in living cells by emitting visible fluorescence. Cell applications indicated that (SB-2) could be used as an excellent fluorescence probe for visualizing of $\mathrm{Al}^{3+}$ ions in cell lines. Furthermore, antibacterial properties of Schiff bases SB-2, SB-3 and SB-4were also explored by disc diffusion method.

\section{REFERENCES}

Altschuler E, 1999. Aluminum-containing antacids as a cause of idiopathic Parkinson's disease. MedicalHypotheses 53(1):22-23.

Baxter NJ, Blackburn GM, Marston JP, Hounslow AM, Cliff MJ, Bermel W, Williams NH, Hollfelder F, Wemmer DE, Waltho JP, 2008. Anionic charge is prioritized over geometry in aluminum and magnesium fluoride transition state analogs of phosphoryl transfer enzymes. Journal of American Chemical Society 130: 3952-3958. 
Benesi HA, Hildebrand JH, 1949. A spectrophotometric investigation of the interaction of iodine with aromatic hydrocarbons. Journal of American Chemical Society 71(8):2703-2707.

Cicekbilek F., Yilmaz B., Bayrakci M., Gezici O, 2019. An Application of a Schiff-Base Type Reaction in the Synthesis of a New Rhodamine-Based Hg(II)-Sensing Agent. Journal of Fluorescence 29:1349-1358.

Dilleen JW, Birch BJ, Haggett BGD, 1999. Electrochemical detection of aluminium using single-use sensors. Analytical Communications 36:363-365.

Ding WH, Wang D, Zheng XJ, Ding WJ, Zheng JQ, Mu WH, Cao W, Jin LP, 2015. A turn-on fluorescence chemosensor for $\mathrm{Al}^{3+}, \mathrm{F}^{-}$and $\mathrm{CN}^{-}$ions, and its application in cell imaging. Sensors and Actuators B: Chemical209:359-367.

Fiebelkorn KR, Crawford SA, McElmeel ML, Jorgensen JH, 2003. Practical disk diffusion method for detection of inducible clindamycin resistance in Staphylococcus aureus and coagulase-negative staphylococci. Journal of Clinical Microbiology41(10):4740-4744.

Gupta VK, Ganjali MR, Norouzi P, Khani H, Nayak A, Agarwal S, 2011. Electro-chemical analysis of some toxic metals by ion selective electrodes. Critical Reviews in Analytical Chemistry 41(4):282-313.

Gupta VK, Shoora SK, Kumawat LK, Jain AK, 2015. A highly selective colorimetric and turn-on fluorescent chemosensor based on 1-(2-pyridylazo)-2-naphthol for the detection of aluminium(III) ions. Sensors and Actuators B: Chemicals 209:15-24.

Gupta VK, Mergu N, Kumawat LK,Singh AK, 2015. A reversible fluorescence “off-on-off” sensor for sequential detection of aluminum and acetate/fluoride ions. Talanta 144(1):80-89.

Gupta SD., Revathi B., Mazaira GI., Galigniana MD., Subrahmanyam CVS., Gowrishankar NL., Raghavendra NM, 2015. 2,4-dihydroxy benzaldehyde derived Schiff bases as small molecule Hsp90 inhibitors: Rational identification of a new anticancer lead. Bioorganic Chemistry 59: 97-105.

Janakipriya S, Chereddy NR, Korrapati P, Thennarasu S, Mandal AB, 2016. Selective interactions of trivalent cations $\mathrm{Fe}^{3+}, \mathrm{Al}^{3+}$ and $\mathrm{Cr}^{3+}$ turn on fluorescence in a naphthalimide based single molecular probe. Spectrochimica Acta Part A Molecular and Biomolecular Spectroscopy 153:465-470.

Jeyanthi D, Iniya M,Krishnaveni K,Chellppa D, 2013. A ratiometric fluorescentsensor for selective recognition of $\mathrm{Al}^{3+}$ ions based on a simple benzimidazole platform, RSC Advances 3:20984-20989.

Job P, 1928. Formation and stability of norganic complexes in solution. Annales de Chimie 9:113-203.

Keskin S, Bayrakci M, 2019. A simple and highly sensitive turn-onschiff base type naked-eye fluorescent sensorfor aluminum ion in living cells. Acta Chimica Slovenica 66(4):792-801.

Kim HM, Jung C, Kim BR, Jung SY, Hong JH, Ko YG, Lee KJ, Cho BR, 2007. Environment-sensitive twophoton probe for intracellular free magnesium ions in live tissue. Angewandte Chemie 46:3460 -3463.

Kim S, Noh JY, Kim KY, Kim JH, Kang HK,Nam SW, Kim SH, Park S, Kim C, Kim J, 2012. Salicylimine-based fluorescent chemosensor for aluminum ions and application to bioimaging. Journal of Inorganic Chemistry 51(6):3597-3602.

LakowiczJR, 2002. Topics in fluorescence spectroscopy: probe design and chemical sensing; Kluwer Academic Publishers: New York, 4-11p.

Murtaza S., Abbas A., Iftikhar K., Shamim S., Akhtar MS., Razzaq Z., Naseem K., Elgorban AM, 2016. Synthesis, biological activities and docking studies of novel 2,4-dihydroxybenzaldehyde based Schiff base. Medicinal Chemistry Research 25: 2860-2871.

Neelakantan MA,Rusalraj F, Dharmaraja J, Johnsonraja S, Jeyakumar T, Sankarayana PM, 2008. Spectral characterization, cyclic voltammetry, morphology, biological activities and DNA cleaving studies of amino acid Schiff base metal(II) complexes. Spectrochimica Acta Part A Molecular and Biomolecular Spectroscopy, 71(4):1599-1609.

Santos-Figueroa LE, Moragues ME, Climent E, Agostini A, Martinez-Manez R, Sancenon F, 2013. Chromogenic and fluorogenic chemosensors and reagents for anions A comprehensive review of the years 2010-2011. Chemical Sociecty Review 42(8):3489-3613.

Shoora SK, Jain AK, Gupta VK, 2015. A simple Schiff base based novel optical probe for aluminium (III) ions. Sensors and Actuators B: Chemicals 216:86-104. 
Simona T, Shellaiahb M, Srinivasadesikanc V, Lina CC, Koa FH, Sunb KW, Linc MC, 2016. A simple pyrene based AIEE active schiff base probe for selective naked eye and fluoresence off-on detection of trivalent cations with live cell application. Sens. Actuators B 231:18-29.

Soni MG, White SM, Flamm WG, Regul GAB, 2001. Safety evaluation of dietary aluminum. Regulatory Toxicology and Pharmacology 33(1):66-79.

Soroka K, Vithanage RS, Phillips DA, Walker B, Dasgupta PK,1987. Fluorescence properties of metal complexes of 8-hydroxyquinoline-5-sulfonic acid and chromatographic applications. Analytical Chemistry 59(4):629636.

Sun X, Liu J, Zhuang C, Yang X, Han Y, Shao B, Song M, Li Y,Zhu Y, 2016. Aluminum trichloride induces bone impairment through TGF- $\beta 1 /$ Smad signaling pathway. Toxicology 14:49-57.

Sztanke K, Maziarka A, Osinka A, Sztanke M 2013. An insight into synthetic Schiff bases revealing antiproliferative activities in vitro. Bioorganic and Medicinal Chemistry 21:3648-3666.

Mozhgan T., Mohammad Y., Kheirollah M., Masoumeh T., Mahmood D.A, 2017. Synthesis, Characterization and Antimicrobial Activity of Two Novel Sulfonamide Schiff Base Compounds. Pharmaceutical Chemistry Journal 51:425-428.

Tian J, Yan X, Yang H, Tian F, 2015. A novel turn-on Schiff-base fluorescent sensor for aluminum(III) ions in living cells. RSC Advances 5:107012-107019.

Zhong Z, Zhang D, Li D, Zheng G, Tian Z, 2016. Turn-on fluorescence sensor based on naphthalene anhydride for $\mathrm{Hg}^{2+}$. Tetrahedron 72(49):8050-8074.

Zhou D, Sun C, Chen C, Cui X, Li X, 2015. Research of a highly selective fluorescent chemosensor for aluminum(III) ions based on photoinduced electron transfer. Journal of Molecular Structures 1079:315320.

ZhuJ, Zhang Y, Wang L, Sun T, Wang M, Wang Y, Ma D, Yang Q, Tang Y, 2016. A simple turn-on Schiff base fluorescence sensor for aluminum ion Tetrahedron Letters 57: 3535-3539.

Walton JR, 2006. Aluminum in hippocampal neurons from humans with Alzheimer's disease. Neurotoxicology 27:385-394.

Wang JT, Wang HD 2011. Preparation of soluble p-aminobenzoyl chitosan ester by Schiff's base and Antibacterial activity of the derivatives. International Journal of Biological Macromolecules 48:523-529. 